\title{
THE IDEA OF IMPLEMENTATION OF THE METROPOLITAN BIKE SYSTEM ON THE EXAMPLE OF THE SZCZECIN METROPOLITAN AREA
}

\author{
GRAŻYNA ROSA, ${ }^{1}$ TOMASZ SONDEJ ${ }^{2}$ \\ ${ }^{1}$ University of Szczecin, Faculty of Management and Economics of Services, POLAND \\ e-mail: grazyna.rosa@wzieu.pl \\ ${ }^{2}$ WSB University in Poznań, Faculty of Economics in Szczecin, POLAND \\ e-mail: tomasz.sondej@wsb.szczecin.pl
}

RECEIVED
ACCEPTED
JEL
CLASSIFICATION

KEYWORDS

ABSTRACT
10 December 2018

28 December 2018

O18, Q56, R41

transportation systems, bicycle system, sustainable development, regional development

The article discusses the idea and objectives of metropolitan areas and, in this context, the conditions for the implementation of the Metropolitan Bike System in the Szczecin Metropolitan Area. The considerations were based on the results of secondary research against the background of changes taking place in the environment of transport companies, which are also an opportunity to develop mobility in cities. The aim of the article is to indicate the reasons for the implementation of the Metropolitan Bike System in the Szczecin Metropolitan Area, on the basis of international and domestic experience. In order to achieve the goal, the desk research method was adopted, taking into account the available literature and the results of secondary research on the Metropolitan Bike System published by the authorities of the Szczecin Metropolitan Area, which open new opportunities for modelling mobility in cities and metropolitan areas. The territory of Poland was chosen as the research area, with particular emphasis put on the Szczecin Metropolitan Area.

\section{Introduction}

One of the basic assumptions of metropolitan areas is coherent interconnection between individual units of a given system. The factors having the greatest impact on this concept include (Kłos-Adamkiewicz, Załoga, 2017, p. 170):

- decrease in the share of public transport and increase in the use of passenger cars in urban areas, 
- increase in the use of other means of transport, which are complementary to public transport services, such as city bikes.

City bikes, i.e. maintenance-free network systems of bicycle rental in cities, are more and more often included in the urban transport systems as an element of mobility modelling. The organization of bicycle transportation in cities, which mainly comes down to the creation of special traffic areas, as well as creation of the so-called "city bikes", can be beneficial for both residents and tourists (Meyer, Sawińska, 2018, pp. 34-42).

In its initial phase, "The Szczecin Metropolitan Area (SMA), covering an area of 2,795 km², is not only developing, but also has a polycentric settlement structure, which is a good condition to achieve sustainable development and increase competitiveness in the European Union" (Koncepcja budowy..., 2017). The Szczecin Metropolitan Area (SMA) consists of the following local government units: Dobra commune, Goleniów municipal commune, Gryfino municipal commune, Kobylanka commune, Kołbaskowo commune, Police commune, Stargard municipal commune, Stargard commune, Stepnica commune, Szczecin municipal commune, Stare Czarnowo commune, Świnoujście city, Nowe Warpno commune, and Police County. The communes of the Szczecin Metropolitan Area carry out various activities to promote and develop bicycle traffic, with their dynamics and detailed scope being diversified. Although these activities are most often associated with the development of the bikeway network, the system solutions for the entire Szczecin Metropolitan Area have still not been created. As part of individual planning documents, the development of the bicycle transportation network and related infrastructure, as well as elements of its promotion, were taken into account.

The aim of the article is to indicate the reasons for the implementation of the Metropolitan Bike System in the Szczecin Metropolitan Area, on the basis of international and domestic experience. In order to achieve the goal, the desk research method was adopted, taking into account the available literature and the results of secondary research on the Metropolitan Bike System published by the authorities of the Szczecin Metropolitan Area.

\section{City bike in Poland}

The bike is becoming an important element of public transport. The quality of city bike systems depends on, among others, the number of vehicles and stations where the bike can be rented and returned, and the location of said bike stations, which is the determinant of not only an effective system, but also a way to commute to work and schools, as well as a tool for managing urban mobility.

Although the beginning of bike sharing dates back to the mid-1960s (Amsterdam - "White Bicycles"), its growth started in the 21st century (Shaheen, Guzman, Zhang, 2010, pp. 159-167, after: Kos, Krawczyk, Tomanek, 2018 , p. 29). These systems are developing very quickly all around the world - an increase from 320,000 rides to over 28 million (55 systems, 42 thousand bikes) was recorded in 2010-2016 in the U.S. (Ranking..., 2018). Today, there are over 140 bicycle rental systems in 165 countries around the world (Dębowska-Mróz, Lis, Szymanek, Zawisza, 2017, pp. 1173-1182). Bicycles, especially in Poland, seem to have a large growth potential in handling mobility. That is why city authorities are developing bicycle systems. Three basic directions of activities in this area include (Kos, Krawczyk, Tomanek, 2018, p. 29):

- development of bike paths and bikeways,

- development of bicycle sharing systems (bike sharing),

- promoting bike sustainable mobility. 
The development of bike paths has become a fact in most Polish cities (Krysiuk, Brdulak, Banak, 2015, pp. 881-886). New cycling routes with different parameters are designated and various solutions facilitating cycling are implemented, e.g. cyclists can use both one-way routes and pavement roads (up to $10 \mathrm{~km} / \mathrm{h}$ ). At the same time, the share of bicycles in mobility in Poland is still low $-3.1 \%$. The share is the highest in the $16-19$ age group (4.90\%), whereas in the group of 20-25 years, it amounts to only 2.9\% (Jacyna, Wasik, Gołębiowski, 2016, pp. 5-11). Daily use of bicycles in Poland is lower than in Western European countries (e.g. Germany - 19\%) (Debyser, 2014).

As far as Poland is concerned, the first system appeared in 2008 in Kraków. Nevertheless, the largest system is Veturilo (351 stations, 5.2 thousand bicycles), which is managed by 5 operators in Warszawa. It is worth noting that Polish systems are generally seasonal. Moreover, an increasing trend is apparent, which concerns especially university cities (Ranking..., 2018). Tasks related to the operation of the city bike system in Poland are carried out by three major operators, with the oldest being BikeU (in operation since 2014 in Poland), and the largest one Nextbike, serving residents in 13 cities and 2 communes (Dębowska-Mróz, Lis, Szymanek, Zawisza, 2017, pp. 1173-1182).

Since 2017, users of maintenance-free city bike systems in Poland have at their disposal more than 10.5 thousand bikes and almost 900 stations, whose operator is mainly Nextbike (over 80\%) (Dębowska-Mróz, Lis, Szymanek, 2017, p. 1175). Warszawa dominates in City Bike Ranking 2018, (43 points, with the next being Lublin - 34 points, and Szczecin - 17 points), where the density of bicycle routes amounts to 1,035 m/km (in Szczecin $449 \mathrm{~m} / \mathrm{km}^{2}$ ), the number of inhabitants per bike is 337 (in Szczecin 547), and the average density of bicycle stations is 0.69 stations $/ \mathrm{km}^{2}$ (in Szczecin 0.28) (Rowerowy..., 2018). For many users it is a "first and last mile" means of transport, i.e. transport to a public transfer node. Another important fact is that the first twenty minutes of riding a city bike are free. This factor is an important incentive for using them. Research shows that $85-90 \%$ of rides take place during the first twenty (free) minutes. Almost a million of Poles benefit from city bikes, with the number of rides being counted in millions (Dębowska-Mróz, Lis, Szymanek, 2017, pp. 1182-1183).

\section{City bike in the Szczecin Metropolitan Area}

Before the Szczecin City Bike was created, the analysis of the conditions for making such a decision was carried out concerning primarily infrastructure, territorial scope, potential demand (population and population density), as well as costs and benefits.

As part of the analysis of the existing infrastructure constituting the basis for creating the Metropolitan Bike System, it is necessary to distinguish the basic indicator, which is the length of bikeways. According to the information presented in the Local Data Bank of the Central Statistical Office, Szczecin has the largest number of bicycle routes (114.7 km, including approx. $100 \mathrm{~km}$ of separate roads for bicycles and nearly $15 \mathrm{~km}$ of lanes for bicycles designated on roadways). The length of the cycling infrastructure in Szczecin is constantly growing, which is the result of both activities carried out directly by the local government and the implementation of projects within the framework of the Szczecin participatory budget. Residents positively assess the implementation of this idea - in its first edition (in 2013), the Szczecin City Bike was the winning project and obtained financing at the level of over PLN 0.5 million. The remaining local government units of the SMA have definitely fewer bikeways. In Police, the second commune in the ranking, there are $39.9 \mathrm{~km}$ of bikeways. A considerable number of cycling infrastructure can also be found in Stargard $(24.2 \mathrm{~km})$ and Świnoujście $(25.2 \mathrm{~km})$. The territorial range of the city bike system in the SMA is determined by three basic parameters: the number of stations per km2, the number of bicycles per 
1,000 inhabitants and the number of docking places per the number of bicycles (Koncepcja budowy..., 2017, p. 23). These parameters determine the number and distribution of bicycle rental/return stations within the analysed area.

In the case of urban areas, the optimal density of bicycle stations is $10-16$ stations per $\mathrm{km}^{2}$. At the same time, when planning the territorial scope and size of the system, the number of bicycles should also be considered in terms of the number of people in the area where the metropolitan bike will operate. In the case of metropolitan bikes, the territorial scope and size of the system itself are much greater than in the case of city bikes, which implies the necessity of even more meticulous preparation of the business model of the investment, so as not to overestimate the financial and organizational capabilities of individual municipalities. The optimal number of bicycles per population is, depending on the degree of bicycle transport usage, 10-30 bicycles per 1,000 inhabitants of the area. Another important parameter is the indicator of docking places per number of bicycles in the system. It is recommended that the number of docking places per number of bicycles in a given system should be about 2-2.5. This reduces the expenses for transporting bikes in order to avoid overloading the station (Koncepcja budowy..., 2017).

In 2016, the SMA was inhabited by nearly 687,000 people. The largest population is recorded in Szczecin $(405,000)$. An important factor in the demand for transport infrastructure, as well as its type, is the population density of a given area. The highest density of population has been recorded in Stargard (1,424 people per $\left.\mathrm{km}^{2}\right)$ and Szczecin $\left(1,347\right.$ people per $\left.\mathrm{km}^{2}\right)$. In the case of these cities, transport solutions aimed at reducing car traffic and increasing the importance of public transport are necessary. The use of a city bike is a good way to reduce traffic and exhaust emission (Koncepcja budowy..., 2017).

The introduction and development of the municipal bike system in the SMA is also determined by the estimate of costs and benefits. Due to the lack of a similarly functioning system in Poland (metropolitan system), it is not possible to accurately estimate the costs related to the construction and operation of the Szczecin Metropolitan Bike. The estimated construction costs (categories) of the Szczecin Metropolitan Bike and its annual operating costs (categories) are presented in Tables 1-2.

The main benefits of creating the Szczecin Metropolitan Bike may include (Koncepcja budowy..., 2017):

- increasing the quality and diversity of the transport system as a factor activating the growth of bicycle traffic in the SMA,

- improving the accessibility to nodes and stations of public transport systems (including S-train),

- increasing the share of bicycle traffic in the travel structure - in the entirety of passenger traffic as an attractive means of transport,

- increasing the quality of life of residents of SMA by improving mobility,

- improving the natural environment and health of residents by reducing the level of exhaust emissions, traffic noise and vibrations.

- improving public health, increasing life expectancy and satisfaction with the quality of life by intensifying the daily physical activity of cyclists,

- encouraging residents to change travel behaviour by popularizing transportation by bike,

- increasing the availability of local workplaces and public places.

The Szczecin City Bike was launched on August 22, 2014 by BikeU and consisted of 32 base stations (Koncepcja budowy..., 2017). 
Table 1. Estimated construction costs (categories) of the Szczecin Metropolitan Bike

\begin{tabular}{lcl}
\hline \multicolumn{1}{c}{ Assets } & Estimated unit cost (PLN) & \multicolumn{1}{c}{ Estimation basis } \\
\hline Bike station & 50,000 & $\begin{array}{l}\text { Analysis of public bicycle systems functioning in Poland (tender values) verified by current, } \\
\text { average market prices }\end{array}$ \\
Warehouse space $\left(\mathrm{m}^{2}\right)^{* *}$ & 800 & $\begin{array}{l}\text { Analysis of current market prices of warehouse space in Zachodniopomorskie Voivodeship } \\
\text { Service station }\end{array}$ \\
Public bike & 80,000 & Analysis of public bicycle systems functioning in Poland (tender values) \\
\hline
\end{tabular}

A bicycle station containing about 15 bike racks.

"Target: $3.5 \mathrm{~m}^{2}$.

Source: Koncepcja budowy..., 2017, p. 119, the presented costs are gross prices.

Table 2. Estimated annual operating costs (categories) of the Szczecin Metropolitan Bike

\begin{tabular}{lcl}
\hline \multicolumn{1}{c}{ Activity } & $\begin{array}{c}\text { Estimated unit cost } \\
\text { (PLN/year) }\end{array}$ & \multicolumn{1}{c}{ Estimation basis } \\
\hline Maintenance of a bicycle station & 6,000 & Analysis of public bicycle systems functioning in Poland (tender values) \\
Relocation & 10,000 & Analysis of public bicycle systems functioning in Poland (tender values) \\
Maintenance of a bicycle station & 6,000 & Analysis of public bicycle systems functioning in Poland (tender values) \\
Maintenance of warehouse space $\left(\mathrm{m}^{2}\right)$ & 50 & Analysis of public bicycle systems functioning in Poland (tender values) \\
Storage of a public bike & 1,000 & Analysis of public bicycle systems functioning in Poland (tender values) \\
Cost of spare parts & 800 & Analysis of current prices of bicycle parts (average market value) \\
Cost of bike service & 200 & Analysis of current prices of bicycle parts (average market value) \\
Other costs & 2,000 & Analysis of public bicycle systems functioning in Poland (tender values) \\
\hline
\end{tabular}

'PLN 10,000 bicycle station/year (average value depending on the number of bikes and distances between stations).

" 2,000 bike/year (averaged such costs as PR, www, media, telephones, liability insurance, accounting, system operation, etc.).

Source: Koncepcja budowy... (2017), pp. 119-120, the presented costs are gross prices.

In 2016, Nextbike Polska won a tender for the expansion of the rental system. Additional stations were created - their total number reached 82, and thus Szczecin joined 13 other cities in Poland operating within the Nextbike network (Dybalski, 2016). The operator of the system is a municipal company called "Nieruchomości i Opłaty Lokalne".

\section{Conclusions}

The conducted analysis of the conditions for the implementation of the Szczecin City Bike, concerning primarily infrastructure, territorial scope, costs and benefits, justify this investment. The first years of its operation also confirmed the relevance of the undertaking. The experience and premises for the implementation of similar systems in the world and Poland indicate that this is an indispensable element of modelling city mobility. Thousands of young people, for whom the city bike is the basic means of transport, live, study, work, and actively spend free time in the university city of Szczecin. For this group, the introduction of the Szczecin City Bike generates real benefits. These include: improving the accessibility to nodes and stations of public transport systems; increasing the share of cycling in the travel structure - in the entirety of passenger traffic as an attractive mode of transport; improving the quality of life (also other residents of SMA) by improving mobility; encouraging change in transport 
behaviour, involving the popularization of cycling transportation; and increasing the availability of local workplaces, as well as education and public spaces.

\section{References}

Debyser, A. (2014). Urban Mobility. Shifting towards sustainable transport systems. Members' Research Service. Brussels: European Parliamentary Research Service. Retrieved from: http://www.europarl.europa.eu/RegData/etudes/IDAN/2014/538224/ EPRS_IDA(2014)538224_REV1_EN.pdf.

Dębowska-Mróz, M., Lis, P., Szymanek, A., Zawisza, T. (2017). Rower miejski jako element systemu transportowego w miastach. Autobusy: technika, eksploatacja, systemy transportowe, 6 (CD), 1173-1182.

Dybalski, J. (2016). Szczecin z nowym, rozbudowanym rowerem Bike_S. Retrieved from: https://www.transport-publiczny.pl/ wiadomosci/szczecin-z-nowym-rozbudowanym-rowerem-bikes-52711.html.

Jacyna, M., Wasik, M., Gołębiowski, P. (2016). Model ruchu rowerowego dla Warszawy wg Warszawskiego Badania Ruchu 2015. Transport Miejski i Regionalny, 10, 5-11.

Kłos-Adamkiewicz, Z., Załoga, E. (2017). Miejski transport zbiorowy. Kształtowanie wartości usługi dla pasażera w świetle wyzwań nowej kultury mobilności. Warszawa: BEL Studio sp. z o.o.

Koncepcja budowy systemu Szczecińskiego Roweru Metropolitalnego (2017). Eu-Consult spółka z 0.o. na zlecenie Stowarzyszenia Szczecińskiego Obszaru Metropolitarnego. Gdańsk. Retrieved from: http://www.som.szczecin.pl/chapter_104027.asp?soid=84 7F3B59F202420FA892250D4A11139F.

Kos, B., Krawczyk, G., Tomanek, R. (2018). Modelowanie mobilności w miastach. Katowice: Wydawnictwo Uniwersytetu Ekonomicznego w Katowicach.

Krysiuk, C., Brdulak, J., Banak, M. (2015). Mobilność i komunikacja w miastach polskich. TTS Technika Transportu Szynowego, 12, 881-886.

Meyer, B., Sawińska, A. (2018). Kierunki rozwoju szlaków rowerowych w województwie zachodniopomorskim. Prace Komisji Geografii Komunikacji Polskiego Towarzystwa Geograficznego, 21 (1), 34-42.

Ranking Systemów Rowerów Miejskich 2018 (2018). Retrieved from: https://www.dadelo.pl/blog/systemy-rowerow-miejskich/.

Rowerowy ranking polskich miast 2018. Które miasto jest najbardziej przyjazne rowerzystom (2018). Retrieved from: https://www. morizon.pl/blog/rowerowy-ranking-miast-2018.

Cite this article aS: Rosa, G., Sondej, T. (2018). The idea of implementation of the metropolitan bike system on the example of the Szczecin Metropolitan Area. European Journal of Service Management, 4 (28/2), 373-378. DOI: 10.18276/ejsm.2018.28/2-44. 